\title{
The Actualization of Religiosity and Community Togetherness in Tawang Susukan Village, Semarang District in Tradition of Sedekah Bumi Merti Desa
}

\author{
S. Sulistiyoningsih; W. A. Rais; Supana \\ Department of Cultural Science, Universitas Sebelas Maret, Surakarta, Indonesia \\ http://dx.doi.org/10.18415/ijmmu.v8i9.2947
}

\begin{abstract}
Sedekah Bumi Merti Desa is one of the typical traditions of the Javanese community which is carried out by farmers in Tawang Susukan Village, Semarang Regency during the harvest season or the period before the planting season. The purpose of this research is to describe (1) the reconstruction of the Sedekah Bumi Merti Desa in Javanese culture which is held in Susukan Village, Semarang Regency which is full of local wisdom, and (2) the aspects of religion and the spirit of sharing values among community members. This research uses descriptive qualitative methods with hermeneutic studies as research strategies and approaches. Data collection techniques are obtained through observation, deep interviews, and documentation. The results of the study indicate that Sedekah Bumi Merti Desa is still practiced by farmers in Susukan Village, Semarang Regency from generation to generation with more modern models and components. This tradition is a form of the local community's gratitude to God for the crops. Furthermore, sharing crops among the local community is done in order to strengthen brotherhood and togetherness. The novelty of this research is to analyze the processions and values in Sedekah Bumi Merti Desaas a form of local wisdom that is still surviving to the present time in the midst of global modernization.
\end{abstract}

Keywords: Sedekah Bumi Merti Desa; Tradition; Ethnography; Local Wisdom; Religious Values

\section{Introduction}

The terminology of Cultural Studies presents a critical form of definition of culture that leads to "the complex everyday world we all encounter and through which all move" (Edgar \& Peter, 1999: 102). Culture in broad definition is the process of daily human life on a general scale, starting from actions to ways of thinking, as the concept of culture described by Kluckhohn. This understanding is also supported by Clifford Geertz (1983). He states that culture is defined as a series of rules, recipes, plans, and instructions that humans use to regulate their behavior. In cultural studies, a concept of culture can be understood along with behavior changes and structure of society in Europe in the 19th century. These changes happen due to the influence of rapid developing technology. The term of culture itself is a comprehensive study to analyzing an object of study. For example, in studying cultural anthropology, sociology, history, ethnography, literary criticism, and even sociobiology need to be studied. The focus of cultural studies lies on the aspects of cultural and power relations that can be seen in pop culture. In the tradition of Cultural Studies in England inherited by Raymonds Williams, Hoggarts, and Stuart Hall, the concept of culture is the most complicated thing to interpret. Therefore, cultural studies are a useful tool for 
them. Thus, local wisdom becomes an interesting study and can be combined with other disciplines as long as it has a strong and acceptable knowledge base for the community (Darasawang, 2015: 4).

The purposes of cultural studies are to understand culture in all its complex forms and to analyze the social and political context in which culture manifests itself (Subandi, 2018). Cultural studies are a place of study/analysis and political criticism. For example, a cultural scholar will not only study a single object, but also connect the study to a larger political project. Cultural studies try to expose and reconcile the constructed divisions of knowledge to be grounded in nature. Cultural studies are committed to the ethical evaluation of modern society. One of the aims of cultural studies is to examine cultural practices and its relation with power, following critical theory.

\section{Theoretical Review}

Cultural studies are the entire system of ideas, actions, and human works in the context of social life which are made by learning (Koentjaraningrat, 1990). Cultural studies are a set of interrelated intellectual and political left practices. Its main aims are: (i) to produce a detailed and contextual analysis of the way social power and relations are created, structured, and maintained through culture; and (ii) to disseminate the analysis in public forums along with the task of pedagogy, provocation, and political intervention. So far this is an academic project, not always (or even primarily) related to communication. On the contrary, cultural studies is a radical interdisciplinary. Its perpetrators can be found in a wide variety of the humanities and social sciences. This includes various practices, including research, theory, pedagogy, activism, criticism, and works of art that are real elements of cultural ritualism in society (Utina, 2019).

The tradition of Sedekah Bumi Merti Desa is the community's tradition to convey gratitude to God and to seek salvation in life (Endraswara, 2006). Sedekah Bumi Merti Desa is a traditional ceremony to express gratitude to God's grace for providing various kinds of needs for mankind. Sedekah Bumi Merti Desa is often done by Javanese in some different places with different names and ways. However, the goals of the ceremony remain the same, to convey gratitude to God and to share goodness with fellow human beings. Humans are God's creatures, so they must be obedient and thankful to God the Almighty (Sih, Y.N., Saddhono K., Budhi S., 2018).

Each region has conceptsand procedures for implementing Sedekah Bumi Merti Desa (Abbas, 2017). The implementation of Sedekah Bumi Merti Desa is adjusted to ancestors' traditions that have been inherited from generation to generation. Generally, various kinds of crops are displayed at Sedekah Bumi Merti Desaceremony as a symbol of abundant crops. The implementation of Sedekah Bumi Merti Desa is always accompanied by the community's belief towards supernatural things that exist outside human dimension. Sedekah Bumi Merti Desathat is practiced by the community in the Tawang Susukan area, Semarang Regency, Central Java is a part of culture because its implementation requires heterogeneous cultural elements.

\section{Method}

The This study used a qualitative research approach with descriptive analysis method. Qualitative method is used to study the background of research subject deeply (Moleong: 2012: 7). The study was a qualitative research with the hermeneutic approach. The data used in this study were the results of observations and interviews with selected informants from the community of Tawang Susukan Village, Semarang Regency. This study took placein Tawang Susukan Village, covering the headman's house. Qualitative research technique is a scientific research process that is more intended to understand human problems in a social context by creating a comprehensive and complex picture, reporting detailed views from information sources, and presenting natural setting without any intervention from researchers (Herdiansyah, 2010: 8). 
Data collection techniques in this study were observation, interviews, and documentation. Data analysis in qualitative research is taken before the study starts, during the study, and after the study. Qualitative data analysis is done by working with data, sorting them into manageable units, synthesizing them, looking for and finding the patterns in order to find valuable results of study.

\section{Result and Discussion}

Sedekah Bumi Merti Desa is a tradition of salvation carried out by farmers after working on the fields or ending the harvest season (Brataiswara, 2000). In this celebration, various types of food are served. The food comes from all crop products. Sedekah Bumi Merti Desais also done as a means to unite the community as well as respect, reminisce, and take care of the village. This is done once a year after the harvest season. This tradition is a traditional ceremony in which is held by the community to express gratitude to God for good harvest, so that they can live happily, safely, and sufficiently with appropriate clothing and food.

\section{Sedekah Bumi Merti Desa as a Cultural Part of Javanese Community}

Broadly, culture means all the works, senses, and creations of the community. Community work produces technology and material culture or physical culture that is needed by humans to master the surrounding environment so that its strength and results can be perpetuated for the needs of the community (Dewalt, 1980). Culture can also be interpreted as a set of values, vital ideas, and beliefs that dominate and guide for behavior patterns of the community itself. Therefore, culture includes all ways of thinking, feeling, and acting. As stated by Peursen who states that culture includes all human actions. For example, humans commemorate death and make ceremonies to celebrate other important events.

Sedekah Bumi ceremony is a typical tradition for community in various regions in Central Java. The philosophy of this tradition comes from the word sadaqah which means "to present and share" and the earth which means "the place of human life". There are many models of Sedekah Bumi that are wrapped according to the conditions of the respective communities. However, the aims of Sedekah Bumi in every region remain the same, as a means to preserve Javanese native culture as well as a means to express gratitude to God the Almighty. Sedekah Bumi is inherited from ancestors from generation to generation. Commonly, this ceremony is carried out by agrarian communities. Each region has its own concept of Sedekah Bumi implementation, so there are various symbols regarding to this ceremony. Sedekah Bumi is always along with beliefs about supernatural things that exist outside human dimension (Bottoms, 2019).

The traditional ceremony of Sedekah Bumi Merti Desa which is held in the Tawang Susukan Village, Semarang Regency is a means of culture because it is a result of human creations and works carried out from generation to generation. Besides Merti Desaprocession contains various cultural elements such as beliefs or religion and arts. Sedekah Bumi Merti Desa is a community tradition from generation to generation. Tawang community does this tradition every year as a thanksgiving to God for the crops. In short, Merti Desa has been closely related to Javanese. Native community who lives in Tawang Susukan Village, Semarang Regency, are predominantly Javanese. They live in the village to carry on the cultural heritage of their ancestors, Sedekah Bumi Merti Desa. However, the community can only broadly interpret that the purpose of Sedekah Bumi is to give something to the earth bymeans of salvation and gratitude to ask for blessings from God the Almighty (Pardji, 2016).

Sedekah Bumi Merti Desa is done once a year at Hijri New Year on Jumat Legi (Friday Legi). The location of the ceremony is at Tawang Village Hall, after the community has harvested their crops, such as rice and tubers. The community in Tawang Susukan Village, Semarang Regency is an agrarian society. The majority of the community is rice and tuber farmers. They strongly believe that if they do not carry out this traditional ceremony, the crops will not grow well and thus the harvest will fail (Hasbullah, Toyo, \& Pawi, 2017). Based on these background thoughts, Javanese ancestors suggested and taught their descendants to keep living up Sedekah Bumi. This activity is carried out by the whole community of Tawang Susukan Village, Semarang Regency so they can work together and help each other. 
The background of tradition is a form of gratitude to God the Almighty for all the good fortune that has been bestowed on the harvest for the whole year. Besides, it is also expected that the harvest in the following year will be full of blessings. This thought is still believed up to the present time. Otherwise, if the community does not continue to live up this tradition, they will be in danger. Therefore, this tradition has become an obligation that must be carried out, not only to avoid danger, but also to preserve local culture and wisdom. The existence of local culture and wisdom in an area should be maintained continuously by the local community (Honko, 2014).

\section{Historical Aspects of Local Wisdom Sedekah Bumi Merti Desa}

Tawang Village was a grassy field that spread out widely. The land was very dry. It is said that there lived a grandmother named Nyi Wono. Nyi Wono had a brother named Kyai Agung Alim, who lived in Jangkrikan, Rogomulyo Village.The two of them competed with each other to expand their land. Kyai Ageng Salim used a sickle to expand his land so he only got a narrow land. Meanwhile Nyi Wono expanded her land by burning the weeds. As a result, her land was very vast, just like awang-awang (sky). It was where the name of Tawang Village came from. One day, Tawang Village was hit by a disease epidemic. Then the village elders took the initiative to hold a ruwatan. Ruwatan is a ceremony that frees people from bad luck. Therefore, the ruwatan itself is held to clean the village from distress and calamity. Ruwatan is held on Jumat Legi (Friday Legi) until now. The traditional ceremony is still commemorated and preserved which is called as "Bersih Desa"or what the community of Tawang Village call "Merti Desa".

Sedekah Bumi is a ritualism that belongs to Nyi Wono, who used to babat alas (open a way) of cultured life as a Javanese in Tawang Village. Actually some other areas around Tawang Village also have Bersih Desa tradition, but the other villages do not do a set of complete procession as Tawang Village. Sedekah Bumi originally came from the Javanese. This tradition had been implemented even before Indonesian independence day (Supriatna \& Nugraha, 2020). The majority of Javanese are farmers who always carry out traditions from generation to generation with the aim of reciprocity between the earth and humans. This tradition is also carried out to have a balanced life with God the Almighty.

Sedekah Bumi which is called as Merti Desa in Tawang Village, is brought by the native Javanese who live in the Tawang Susukan area, Semarang Regency. Due to geographical location, mostly Tawang community live as farmers. Those people are still closely related to the terms of berkah desa (village blessing), tolak bala (reject bad luck), and berkah bumi(earth' blessings). They believe that doing Merti Desa will bring blessings and bountiful harvests. The community believes that if they leaveruwatan, there will be a disaster for the whole village. Sedekah Bumi is carried out with the hope that the following year will be better and be blessed by God the Almighty, as well as be avoided from all calamities. This belief has been believed by Tawang communityfor years. Finally, this is the background of the implementation of Sedekah Bumi Merti Desa in Tawang Susukan Village.

\section{The Ceremony of Sedekah Bumi Merti Desa}

The procession of Sedekah Bumi Merti Desa in Susukan Village, Semarang Regency is carried out sequentially. This ceremony is done once a year. Sedekah Bumi in Tawang Susukan Village, Semarang Regency has 3 main rituals, namelycutting cemanichicken (black Javanese chicken), feasting together, performing shadow puppet. Each of these rituals contains useful meanings and purposes for human life guidelines.

First, the cutting of cemani chicken is a symbol to sacrifice all things that are given by God to humans. In addition, the black color of cemani chicken symbolizes distress that exists around the community. So that by cutting the black cemani chicken, it can prevent people from harm, neglect, and evil. Second, feasting together is started by praying together and continued by sharing food from the crops to symbolize cooperation. Third, the shadow puppet show symbolizes relevant life of Tawang community. Its characters and stories depicts the real life of Tawang community.

Sedekah Bumi Merti Desa is carried out just before Hijri New Year on Jumat Legi (Friday Legi).

The Actualization of Religiosity and Community Togetherness in Tawang Susukan Village, Semarang District in Tradition of Sedekah Bumi Mert 
The exact date should be discussed with the representative elders. This ceremony has never been absent because the community believe that if it is not carried out, there will be a disaster to the village. The community is worried that something bad will happen in their neighborhood.

The timing of Sedekah Bumi Merti Desa is carried out just before Hijri New Year because the community aims at welcoming the New Year, as well as means that the life to come must be more blessed and better than the previous year. This ceremony is also done by rice and tuber farmers to give thanks to God the Almighty for his blessings. The community hopes that they will always be blessed by God the Almighty.

Sedekah Bumi Merti Desa is attended by 11 hamlets in the Susukan area of Semarang Regency, Central Java. The ritual starts by cutting cemani chicken. Then, the filling of the chicken body such as intestines and liver are used as offerings wrapped in banana leaves. The wraps are then planted in every corner of Tawang Village as a village "fence". The whole chicken cemani'sbody is cooked as ingkung. Then, the ceremony begins with the kenduri procession. The food and dishes are served in the form of chicken ingkung along with kenduri rice that is wrapped in banana leaves. The community usually sit in a circle around the kenduri rice and eat together. After that, the community pray together asking for safety and welfare for themselves (Warisno, A., \& Tabrani, Z. A., 2018).

There is also gunungan in this ceremony. Gunungan is a form of a mountain made from food and crops at a traditional ceremony. Inside the gunungan, there is a tumpeng called Ancak which is served according to a predetermined time. Ancakan is a gunungan that contains various forms of crops and fruits with colorful flags that is very attractive. The crops and fruits themselves come from their own land that the farmers strive in Tawang Village. The tumpeng and ancakan are accompanied by art performances such as Reog, Jaran Braid, and other traditional performances.

All series of Merti Desa ceremony should not be left.According to the old rule, the ceremony must be sequential.The community must obey the elders who have been trusted to lead this traditional ceremony from year to year. This rule should not be broken or else they believe that something bad will happen to the village. Therefore, they try their best not to leave this ceremony. The community is always enthusiastic in preparing for Sedekah Bumi Merti Desa ceremony procession.

The main purpose of Sedekah Bumi Merti Desa procession is a form of gratitude to God. Besides, due to this ceremony, inner relation between the community will increase as they should gather to prepare anything needed for the ceremony. This tradition is still running today because it has many positive values. This unique cultural ceremony becomes a tourism potential. It attracts domestic and international tourists. This ceremony is held sequentially. The art performances are done by local people. The shadow puppet show is held all night long with Dewi Sri "Lumbung Padi" as the main character. This character is taken because the village itself is a home for an agricultural community. It can be said that the play adapts to the conditions of the local community.

\section{The Values of Life in Sedekah Bumi Merti Desa}

Every cultural process must have certain objectives. For example, Sedekah Bumi Merti Desa has an objective to express gratitude for good harvest. It also aims to preserve the culture that has existed from generation to generation. In addition, there are several life values in this ceremony which are useful for the life of Javanese community in Tawang Susukan Village, Semarang Regency. The values of Merti Desa are as follows.

\section{1) Sociological Value}

The most important thing in Sedekah Bumi Merti Desa is to provide socio-religious meaning to the community who does the ceremony. This ritual is able to give positive impact and lead the community to a better direction, as well as increase the unity of the community.

2) Theological Value 
Surrender to God and respect the ancestors have become the characters of Javanese community who live in agricultural villages as farmers. This concept is carried out by the community of Tawang Susukan Village, Semarang Regency.

3) Ecological Value

Sedekah Bumi Merti Desa is a means for the community to protect their environment so that it remains natural and preserved. The use of natural materials has good impact on the environmental sustainability of the village.

This ceremony is an asset that contains very high local wisdom for the community. This tradition belongs to the community, therefore it must be maintained and preserved so that the traditional values will always exist. The role of the community is very important for the preservation of a culture. They must pay attention to this tradition and live it up. Young generation also have to take a big role in the preservation. Apart from that, the role of elders is also very important to give direction to young generation by teaching this tradition and participating in the procession.

Merti Desa also involves the value of togetherness in its preparation and implementation. This can be seen from how the elders and the young people gather to prepare the ceremony. Through this gathering, young generation can learn and understand the ceremony deeper. So that there will be a successor who will continue and lead the ceremony in the future. The gathering is now more open because many young people take part in this gathering. Even they are trusted to take care of shopping matters such as groceries and others. In the past, the community only relied on elders and the meetings were a little closed. All of them actively participate in these events, gotong royong (mutual cooperation) is always prioritized to achieve common interests.

Young people play an active role in art shows. They practice at their best to show the best performance during the procession. All young people think that participating in this ceremony is the same as preserving. All community members work together at each ritual. These traditions have been upheld from the past to the present, while being adjusted from time to time due to dynamic human development and modernization (Ungar, M., Ghazinour, M., \& Richter, J., 2013).

Gotong royong is an identity of the Javanese community. Each community member takes his part. Women and girls gather to prepare dishes, while men and boys prepare the necessities for the procession such as planting cemani chicken intestines in every corner of the village and making gunungan.

\section{Conclusion}

The Sedekah Bumi Merti Desa is an ancestral heritage inherited by the elders of Tawang Susukan Village, Semarang Regency. The community of Tawang Village interpret Sedekah Bumi Merti Desa as a form of gratitude for God's blessings for the earth and crops. In addition, the community also asked for God's protection from danger and bad luck that can endanger Tawang community's safety. Therefore, this ceremony is still well preserved by the community up to this day. Apart from being part of the culture, the Javanese view makes this ceremony still be preserved. No one dares to leave this tradition because of the belief that bad luck may occur to the village if the community ever leave it.

Based on the results of the analysis, it can be concluded that: (1) Sedekah Bumi Merti Desa has a purpose to give something to the earth for the crops. As an agrarian community who mostly work as farmers, they are very close to tradition. They believe that by giving Sedekah Bumi, they express gratitude to God Almighty for the crops. They also hope that the crops of the following year will be even more blessed. Last, they believe that if the ceremony is abandoned, there will be a disaster; (2) Sedekah Bumi Merti Desa is carried out once a year at Hijri New Year. There are some sequences of events, starting from cutting cemani chicken (black Javanese chicken), feasting together, and performing shadow puppet. Everything is done on the same day, Friday Legi.

\section{References}

The Actualization of Religiosity and Community Togetherness in Tawang Susukan Village, Semarang District in Tradition of Sedekah Bumi Mert 
Abbas, A. 2017. Kesenian Ojhung Dalam Tradisi Sedekah Bumi Di Desa Bunbarat Kecamatan Rubaru Kabupaten Sumenep Tahun 1960-2005. Avatara, 5(1).

Bottoms, B. L. 2019. An Analysis of Ritualistic and Religion-Related Child Abuse Allegations. Religious Studies: an International Journal, 7(2), 199-214.

Bratasiswara, Harmanta, R. 2000. Bauzvarna Adat Tatacara Jawa. Jakarta: Yayasan Sunurat.

Darasawang, P., Reinders, H., \& Waters, A. 2015. Innovation in language teaching: The Thai context. In Innovation in language learning and teaching (pp. 1-14). Palgrave Macmillan, London.

Dewalt, B.R da..n K.M. Dewalt. 1980. Agricultural Decision making: Antropological Contributions to Rural Development. PF. Barlet (ed). New York: Academic Press.

Edgar, Andrew \& Peter Sedgwick. 1999. Key Concept in Cultural Theory. London and New York. Routledge. Edward (ed).

Endraswara, S. 2006. Mistisisme dalam Seni Spiritual Bersih Desa di Kalangan Penghayat Kepercayaan. Jurnal Kejawen, 1(2), 38-57.

Geertz, Hildred. 1983. Keluarga Jawa. Jakarta: Grafiti Press.

Hasbullah, H., Toyo, T., \& Pawi, A. A. A. 2017. Ritual Tolak Bala Pada Masyarakat Melayu (Kajian Pada Masyarakat Petalangan Kecamatan Pangkalan Kuras Kabupaten Pelalawan). Jurnal Ushuluddin, 25(1), 83-100.

Herdiansyah, Haris. 2010. Metode Penelitian Kualitatif untuk Ilmu-Ilmu Sosial. Jakarta: Salemba Humanika.

Honko, L. 2014. Religion, Myth, and Folklore in the World's Epics. Kalevala and Its Predecessors, 19596.

Koentjaraninngrat. 1990. Pengantar Ilmu Antropologi. Jakarta: Djambata.

Moelong, Lexy J. 2012. Metodologi Penelitian Kualitatif. Bandung: PT Remaja Rosdakarya.

Parji, P. 2016. Socio-Cultural Values of Nyadran Traditional Ceremony in Tawun, Ngawi, East Java, Indonesia. SOSIOHUMANIKA, 9(2), 287-296.

Sih, Y. N., Saddhono, K., \& Setiawan, B. 2018. Religious Value in Nyadran Ceremony in Ngepringan Village, Sragen. El Harakah, 20(2), 155.

Subandi, M. A., \& Good, B. J. 2018. Shame as a cultural index of illness and recovery from psychotic illness in Java. Asian Journal of Psychiatry, 34, 33-37.

Supriatna, R. A., \& Nugraha, Y. A. 2020. Menguak Realitas Praktik Sedekah Bumi Di Desa Ciasmara Kecamatan Pamijahan Kabupaten Bogor. Jurnal Penelitian Sosial Ilmu Komunikasi, 2(1).

Ungar, M., Ghazinour, M., \& Richter, J. 2013. Annual research review: What is resilience within the social ecology of human development?. Journal of child psychology and psychiatry, 54(4), 348-366.

Utina, U. T. 2019. Functions of Barongan Performance Arts Exhibit at The Sedekah Bumi Ritual Ceremony. In 2nd International Conference on Arts and Culture (ICONARC 2018) pp. 119-122. 


\section{Atlantis Press.}

Warisno, A., \& Tabrani, Z. A. (2018). The Local Wisdom and Purpose of Tahlilan Tradition. Advanced Science Letters, 24(10), 7082-7086.

\section{Copyrights}

Copyright for this article is retained by the author(s), with first publication rights granted to the journal.

This is an open-access article distributed under the terms and conditions of the Creative Commons Attribution license (http://creativecommons.org/licenses/by/4.0/). 